Information Management and Business Review

Vol. 5, No. 11, pp. 531-537, Nov 2013 (ISSN 2220-3796)

\title{
Corporate Governance and Firm Free Cash Flows: Evidence from Malaysia
}

\author{
*Razieh Adinehzadeh, Romlah Jaffar \\ University Kebangsaan Malaysia, Malaysia \\ *r_adinehzadeh@yahoo.com
}

\begin{abstract}
This study provides view of free cash flow and corporate governance (CG) by addressing the relationship between audit committee characteristics with free cash flow. Specifically, this study explores whether audit committee characteristics are substitutes to control agency problem regarding to free cash flow within Malaysian firms. The data set comprise of 200 firm observations Malaysian companies for four consecutive years, which comprise of 2005 to 2008. The results show that size of audit committee, frequency of audit committee meeting, proportion of audit committee independence is positively associated with level of free cash flow (FCF). The results of study highlight the importance of corporate governance mechanism, in the form of audit committee characteristics, in the management of cash flow.
\end{abstract}

Keywords: Free cash flow, audit committee characteristics, corporate governance, agency problems, Malaysia

\section{Introduction}

The concept of free cash flow has been introduced by Jensen (1986), in which it refers to the amount of cash which is in surplus that can finance projects that have positive net present values. Managers (agents) can allocate the free cash in a profitable investments or spend it inefficiently in restructuring plans to increase the size of the firm for the purpose of increasing managers' remuneration (Dorff, 2006). On the other hand, manager could also spend the free cash flow as dividend payment to shareholders. Therefore, management decision on free cash allocation could reduce or increase the agency problem within a firm. As stated in agency theory, when ownership and control are separated management's interest can deviate from owners' interests (Jensen, 1986). Therefore controlling and monitoring decisions by the management becomes essential for the board of directors in order to protect the interest of shareholders (Fama \& Jensen, 1983). Board of directors and audit committee are the body primarily responsible for management in corporate governance structure of a firm, which include the internal governance of a firm. Subsequently, the committee evaluate the effectiveness of managers in the allocation and management of free cash flow. This study focuses more on audit committee characteristics, which consists of members of the board that helps in overseeing the management of free cash flow and the financial reporting process. The audit committee provide a communication bridge between management and the internal and external auditors (Carcello \& Neal, 2000).The BRC (1999) states that an audit committee which has more independent members, who are financially literate, hold more frequent meetings and, and larger in size is better capable to evaluate management's decision on accounting issues and reporting activities.

This study, considers audit committee characteristics in order to study if it has any relationship with level of free cash flow of a firm. The argument is since corporate governance attributes such as audit committee characteristics, which are called internal governance within a firm, alleviate agency problems in a firm especially by considering the modern business world. Therefore, the main objective of this research is to examine whether there is any relationship between internal governance characteristics and free cash flow. This study considers the audit committee as the body primarily responsible for management in corporate governance structure of a firm. The study focuses on the analysis of audit committee characteristics and its interrelationship with free cash flow. In particular these attributes of corporate governance variables are examined to determine how they impact free cash flow using a unique complete dataset of Malaysian listed firms. The main contribution of the current study it its being the first study, to the best of our knowledge, to examine the relationship between audit committee characteristics and amount of free cash flow. This study allows us to establish the significant relationship between these two with focus on internal governance in corporate governance. Another contribution discovers that most previous studies about these subjects have 
been carried out in developed countries. But, this study was done in Malaysia, where the capital market is at the infancy stage.

\section{Literature Review}

Agency theory defines the relationship between management and stockholders as a contract between agents and principals. The agent's behavior is conditioned by implicit and explicit incentive structures stated in the contract. Agency problem goes up when the managers or agents make decisions in the best interests of themselves without considering shareholders' interests. Jensen (1986) states that agency problems which are related to equity are due to the existence of excessive free cash flows at the discretion of manager (agent). Jensen (1986) explained free cash flow as: "The extra cash or in surplus of that needed to fund all projects that have positive net present values when discounted at the appropriate cost of capital." So, free cash flow follows a particular conflict between managers and shareholders because managers have control over this amount. So, when firms have extra cash there is a risk of spending it in projects with no added value than having good opportunities for investment. Normally, the managers prefer to spend this money instead of allocating the money among shareholders in the form of dividends. Managers are not certain whether the growth rate would stay the same for the next year hence they are cautious of distributing the free cash flow as dividend among shareholders. On the other hand, Jensen (1986) free cash-flow hypothesis suggest that if firms have cash in excess of their requirement of investment in positive net present value projects, it is better to pay these cash as dividend in order to reduce managerial discretionary of funds and thus avoid agency costs of free cash flow. The literature on cash holding and capital structure normally regards the policies of firms to keep more cash if potential cash flows are more unstable and investment opportunities are less expected in the future (Opler et al., 1999). Corporate governance characteristics are predicted to influence the level of free cash flow.

Audit Committee Size: An effective audit committee can control and monitor the performance of management. However its effectiveness can depend on its size (Vinten, 1993). The dependence theory states that there is a positive association between size of an audit committee and financial performance of firm (Pierce \& Zahra, 1992). Accordingly, the audit committee becomes more effective when the size of the committee goes up, due to the fact that when company faces problems, it has more resources (man power) to solve these problems. When the size of the committee is big, it is also means there are more skills and knowledge sharing which can be utilized to monitor the financial reporting and procedure. BRC (1999) suggest that audit committees must consist of at least three members and at least one of its members should be financially literate. Research has shown that the audit's size is a significant aspect in governance structure; although the consequences are uncertain on whether having smaller size is better than larger ones (see for examples (Dalton et al., 1999; Eisenberg et al., 1998; Yermack, 1996). There is mixed results of the effect of audit committee's size towards performance. A small audit committee size may be more efficient due to less involvement in technical issues. Therefore, audit committee with smaller size may provide a better oversight in financial reporting issue. On the other hand, a larger audit committee may provide a wider range of experience and expertise. Other studies indicate a positive but a weak relationship between the size of audit committee and a company's performance (Eichenseher \& Shields, 1985; Menon \& Deahl Williams, 1994; Pincus et al., 1990). The results from prior studies are not clear about the effect of audit size committee on firm performance. However, this study predict the efficiency of audit committee increases while the size of the audit committee goes up especially in matters that company face problems because it has more options for resolving issues.

\section{H1: There is a relationship between audit committee size and free cash flow.}

Audit Committee Independence: An audit committee member who is independent is also considered as efficient (Raghunandan et al., 2001). Independent audit members lead to the improvement in the independency between management and external auditors (Abbott et al., 2004) by accurately communicate issues within the firm to the management (Raghunandan et al., 2001). Additionally, independent audit committee possesses higher business knowledge which leads to less accounting conflicts. Raghunandan et al. (2001) further suggest that independent audit committees assess the internal auditing plans of a firm and its achievements and protect the shareholder's interests (DeZoort and Salterio, 2001). Therefore audit committee members should be independent of the management. Accordingly, the independent audit 
committee members would ensure better financial management of companies, which also include the management of free cash flow. Therefore, the hypothesis is stated as follows.

H2: There is a relationship between audit committee independence and free cash flow.

Frequency of Audit Committee Meeting: An effective audit committee should carry out its tasks diligently for the purpose of achieving its goals and purposes (FCCG, 1999)Since diligence is difficult to monitor directly, past researchers utilizes audit committee meeting regularity as a substitute for diligence (Raghunandan \& Rama, 2007). Meeting frequency is measured as the number of audit committee meetings held during the year. An effective audit committee should carry out its tasks diligently for the purpose of achieving its goals and purposes (FCCG, 1999)Since diligence is difficult to monitor directly, past researchers utilizes audit committee meeting regularity as a substitute for diligence (Raghunandan \& Rama, 2007). The BRC (1999) and the also state that an audit committee inside a firm should have a meeting at least four times during a financial year. The committees plan and make decision during these meetings. In addition, making decisions on free cash flow could be done during these meetings, which are an important factor of this study by regarding if there is any relationship with free cash flow with audit committee meetings. Previous studies show that the number of financial reporting issues decrease when an audit committee meets frequently during a year. A more frequent meeting during a year with the outside auditors also means that problem related to financial matter and auditing can be resolved more quickly(Raghunandan \& Rama, 2007). Therefore, it is predicted that an audit committee who meet more frequently, would be able to resolve many financial related issues, which also include the decision on the spending free cash flow.

H3: There is a positive relationship between audit committee meeting and free cash flow.

Financial Expertise: To be an effective and efficient board structure, at least one members of audit committees need to be financially literate (Abdul Hamid et al., 1999). Malaysian Code of Corporate Governance has stated this specific requirement in which a minimum of one member of audit committee must be a financial expertise a firm (Rahman \& Ali, 2006). DeZoort and Salterio (2001) state that financial expertise within an audit committee might increase the probability that discovered objects will be associated with the audit committee structure. These kinds of audit committee members are more capable for controlling and monitoring internal governance inside a firm and in order to recognize and solve different financial and accounting problems which can happen inside a firm (Zhang et al., 2007). In addition, audit committees which include financial experts would have more connection with their internal auditors inside a firm(Raghunandan et al., 2001).Audit committee structures who have more financial skills could recognize easier auditor opinions and can prevent the auditors in conflicts which happened inside a firm between management and shareholders (DeZoort \& Salterio, 2001) .So, according to prior studies there is an association between financial expertise and management conflicts and it could lead to affecting management decision on spending free cash flow. In this research the relationship between free cash flow and financial expertise is considered. Therefore, existing audit committee members with financial expertise lead to have effective and efficient internal governance. But, making decisions on keeping or spending free cash flow is still questionable in firms even when there is powerful internal governance.

H4: There is an association between audit committee financial expertise and free cash flow.

\section{Methodology}

Sample: The research sample consists of 50 firms (200 observations) for four consecutive years, from 2005 until 2008. The sample includes non-financial firms, which consider the financial statements especially their cash flow statements and income statement and the other data that are related to this research. The sampling method, which has been used for this research is simple random sampling.

Data Collection: The data used for this study was hand collected from annual reports retrieved from the official website of Bursa Malaysia. Hand collected data has a number of benefits. The foremost benefit is, since hand collected data source is primary and official, it is also more accurate and higher in quality than secondary data sources (Abbott et al., 2004). This research uses cross-sectional method to collect data. 
Measurement of variables: We utilize the cross-sectional regression model in order to test if there is any association between audit committee characteristics (audit size, audit independence, audit committee meetings, audit financial expertise) with free cash flow. The research equation is as follows:

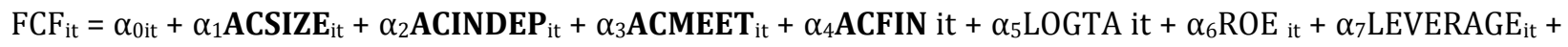
$\alpha_{8}$ LOGDPS $_{\text {it }}+\varepsilon_{\text {it }}$

Where:

FCF $=$ Free cash flow (profit after tax - changes in capital expenditure + depreciation \& amortization - changes in working capital)

ACSIZE $=$ total of audit members

ACINDEP $=$ proportion of independent audit members

ACMEET $=$ number of meeting held by audit committee

ACFIN= proportion of financial expertise of audit committee members.

$\mathrm{ROE}=$ net profit before interest and tax divided by total equity

LEVERAGE $=$ total debt divided by total assets

LOGTA $=$ logarithm of total assets

DPS= dividends per share

\section{Results}

Descriptive Statistics: Table 1 shows the descriptive statistics of sample of the study. The average free cash flow of sample of firms is RM37, 558,053 (range from minimum of RM $(9,399,564,224$ ) to maximum of RM9, $352,462,697$ ) for the year of 2005-2008. The mean size of audit committee members (ACSIZE) is about 3 revealing that the size of the audit committees is considerably low in Malaysia. The mean percentage of audit committee independence and audit committee meeting is about $73.5 \%$ and 4.755 , respectively. Similarly, audit committee's financial expertise percentage is $32.9 \%$. Additionally, the mean for frequency of audit committee meeting is about 5 meetings a year with a maximum of 8 and minimum of once. On the other side, the minimum of total assets (TA) as the first control variable in this study is RM 25,000,000 while its maximum is RM17, 621,224,000. The next one is ROE, which indicates changes from the minimum of (1.560) to 2.899 and the mean of 0.153. LEVERAGE, as shown in this table, shows a minimum value of 0.006 and a maximum of 2.450. The last control variable is DPS with a mean of 0.111 for the period of 2005 until 2008 among selected firms in Malaysia for 2005-2008.

Table 1: Descriptive Statistics of Sample Firms (2005-2008)

\begin{tabular}{lllll}
\hline Variable & Mean & Maximum & Minimum & Std Dev. \\
\hline FCF & $37,558,053$ & $9,352,462,697$ & $(9,399,564,224)$ & $1,296,102,543$ \\
ACSIZE & 3 & 8 & 3 & 0.77 \\
ACINDEP & 0.735 & 1.000 & 0.250 & 0.158 \\
ACMEET & 4.755 & 8.000 & 1.000 & 0.964 \\
ACFIN & 0.329 & 0.750 & 0.00 & 0.156 \\
TA (RM) & $1,608,529,181$ & $17,621,224,000$ & $25,000,000$ & $2,704,604,476$ \\
ROE & 0.153 & 2.899 & $(1.560)$ & 0.460 \\
LEVERAGE & 0.479 & 2.450 & 0.006 & 0.359 \\
DPS & 0.111 & 2.650 & 0.000 & 0.370 \\
\hline
\end{tabular}

Note: FCF $=$ Free cash flow, ACSIZE $=$ total of audit committee members, ACINDEP $=$ proportion of independent audit members, ACMEET = number of meeting held by audit committee, ACFIN = proportion of financial expertise of audit committee members, $\mathrm{ROE}=$ net profit before interest and tax divided by total equity, LEVERAGE $=$ Total debt divided by total assets, $\mathrm{TA}=$ Total Assets, LOGDPS $=$ Dividends per share .

Correlations Matrix of Variables: Table 2 presents the correlations between the variables. According to this table, all the variables have a significant relationship with free cash flow. It shows that there is a considerable association between audit committee meeting and FCF. In addition, based on this table there is a positive correlation between all independent variables with free cash flow except audit committee financial expertise. Likewise, it is reflected for control variables in this study excluding leverage. Lastly, as none of our 
independent variables demonstrate any correlation value of above 0.7 , further tests are applied to investigate the existence of relationship, which is applied in the next part.

Table 2: Correlation Matrix for Sample Firms (2005 - 2008)

\begin{tabular}{|c|c|c|c|c|c|c|c|c|c|}
\hline & LOGFCF & ACSIZE & ACINDEP & ACMEET & ACFIN & LOGTA & ROE & LEVERAGE & LOGDPS \\
\hline LOGFCF & 1.000 & & & & & & & & \\
\hline ACSIZE & 0.151 & 1.000 & & & & & & & \\
\hline ACINDEP & 0.072 & $(0.176)$ & 1.000 & & & & & & \\
\hline ACMEET & 0.200 & 0.003 & 0.022 & 1.000 & & & & & \\
\hline ACFIN & $(0.071)$ & 0.039 & 0.085 & 0.030 & 1.000 & & & & \\
\hline LOGTA & 0.576 & 0.050 & $(0.045)$ & 0.090 & 0.093 & 1.000 & & & \\
\hline ROE & 0.286 & $(0.064)$ & $(0.007)$ & 0.035 & 0.017 & 0.052 & 1.000 & & \\
\hline LEVERAGE & $(0.021)$ & $(0.020)$ & 0.103 & $(0.144)$ & $(0.115)$ & $(0.190)$ & 0.161 & 1.000 & \\
\hline LOGDPS & 0.332 & 0.009 & $(0.060)$ & $(0.050)$ & 0.067 & 0.244 & 0.632 & 0.065 & 1.000 \\
\hline
\end{tabular}

Multivariate Results: Table 3 represents the regression results of the sample for the year of 2005-2008. The adjusted $\mathrm{R}^{2}$ is $48.1 \%$ for Model 1 and $41.9 \%$ for Model 2 . Model 1 includes independent and control variables, whereas in Model 2 it includes only control variables. The results show that audit committee size (ACSIZE) is positively significant at one percent level. It means that when the ACSIZE is higher the FCF is more and vice versa. The relationship between audit committee's size and firm financial presentation is supported by the dependence theory (Pearce \& Zahra, 1992). Therefore H1in this study is accepted.

Table 3: Results of Regression for Sample Firms-FCF (2005-2008), $\mathbf{n}=200$

\begin{tabular}{lllll}
\hline & MODEL 1 & \multicolumn{3}{c}{ MODEL 2} \\
VARIABLES & Coefficient & t-Statistic & Coefficient & t-Statistic \\
\hline Constant & -1.039 & -1.172 & .662 & .811 \\
ACSIZE & .199 & $2.678^{* * *}$ & & \\
ACINDEP & .789 & $2.178^{* *}$ & & \\
ACMEET & .178 & $2.987^{* * *}$ & & \\
ACFIN & -.113 & -1.630 & & \\
LOGTA & .750 & $8.596^{* * *}$ & .792 & $8.647^{* * *}$ \\
ROE & .323 & $2.017^{* *}$ & .312 & 8.647 \\
LEVERAGE & .130 & .831 & .168 & 1.028 \\
LOGDPS & .181 & .976 & .100 & .516 \\
R & 0.511 & & 0.436 & \\
Adjusted R ${ }^{2}$ & 0.481 & & 0.419 & \\
F-statistic & 16.874 & & 25.659 & \\
\hline
\end{tabular}

Note: FCF $=$ Free cash flow, ACSIZE $=$ total of audit committee members, ACINDEP= proportion of independent audit members, ACMEET $=$ number of meeting held by audit committee, ACFIN=proportion of financial expertise of audit committee members, $\mathrm{ROE}=$ net profit before interest and tax divided by total equity, LEVERAGE $=$ Total debt divided by total assets, LOGTA $=$ Total Assets, LOGDPS=Dividends per share.

$* * *, * *, *$ Statistically significant at the $1 \%, 5 \%$, and $10 \%$ respectively

The results indicate that the audit committee independence variable (ACINDEP) is also positively significant at 5 percent level. It illustrate that when the percentage of independence of audit committee is higher the amount of free cash flow also become higher. Therefore $\mathrm{H} 2$ is accepted. Prior studied stated that independent audit committee members considered efficient (Abbott et al., 2000; Hussain \& Mallin, 2003). The audit 
members who are efficient assess the internal auditing plans to protect shareholder's interests (DeZoort and Salterio (2001). Accordingly, the independent audit committee members would ensure better financial management of companies, which also include the management of free cash flow. The results show that variable ACMEET has shown positive relationship with FCF and it is significant at one percent level. Therefore, $\mathrm{H} 3$ is also accepted meaning that the frequency of audit committee meetings effect on amount of FCF. It means that more audit committee meeting leads to more amount of free cash flow. Audit committee must prepare its members with sufficient time with the aim of performing their tasks of controlling their company's financial reporting procedure. Consequently BRC (1999) recommended that audit committee members meet a minimum four times (quarterly) during a year and discuss about financial reporting quality and accounting issues and control related matters with outside members and directors. Frequent meeting can lead to better monitoring of firm's financial reporting process and therefore making better decision on firm's long-term planning. The regularity of the meeting should also depend on the nature of tasks and activities as to ensure that the audit committee achieves their goals and purposes. Therefore, having more meetings can improve the internal governance procedures and also the firm's free cash flow. Consequently, the amount of free cash flow can be directly related with audit committee meetings.

The last variable, financial literacy of audit committee members (ACFIN) show a non-significant relationship with FCF. Although, it is in positive coefficient sign but, there is no significant relationship with these two variables. Therefore H4 cannot be accepted. The SEC (1999) requires that each audit committee consist of a minimum one member who is considered as financial experts. Our result is not consistent with DeZoort and Salterio (2001) that state an audit committee which has financial expertise lead to discovering the objects which are related to audit committee communication with management. The other variables in the regression model are control variables, which are tested against FCF. The size (LOGTA) and profitability (ROE) are statistically significant with positive relationship whereas LEVERAGE and LOGDPS both are insignificant. Also, there are in opposite sign of coefficient, which means that they are in positive and negative relationship with FCF, respectively. As shown in the Table 3 LEVERAGE is in positive sign while LOGDPS is in negative sign with free cash flow in this study.

\section{Conclusion}

This study examines the association between audit committee characteristics with free cash flow. Audit committees members are to maintain integrity of their monitoring function. Data of this study was collected at a single point of time (cross-sectional) to measure the relationship between dependent variable and independent variables in 2005 - 2008. The results show that size of audit committee, frequency of audit committee meeting, proportion of audit committee independence is positively associated with level of free cash flow (FCF). When the size of the audit committee is big, it means there are more skills and knowledge sharing, which can be utilized to monitor the financial reporting and procedure. The positive relationship between frequency of meeting with free cash flow can be interpreted that having more meetings could lead to having more discussion and decision that contribute to keeping more free cash flow than spending it on the managers' interests. When audit committees are diligent in carrying out the audit duties they have would keep more free cash flow in a firm. The results also show a significant positive relationship between audit committee independent with free cash flow. An audit committee member who is independent is considered as efficient (Kannan Raghunandan et al., 2001) especially in solving conflicts between managers and shareholders. Future studies could examine a larger sample of companies in Malaysia to strengthen the conclusions of our study. Also, this study focus the firms in Malaysia to collect and analyze the data, however, the effect corporate governance and internal governance may be different from a broader view by including wider geographical area for the future studies. The results of study highlight the importance of corporate governance mechanism, in the form of audit committee characteristics, in the management of cash flow.

\section{Refrences}

Abbott, L. J., Park, Y. \& Parker, S. (2000). The effects of audit committee activity and independence on corporate fraud. Managerial Finance, 26(11), 55-68.

Abbott, L. J., Parker, S. \& Peters, G. F. (2004). Audit committee characteristics and restatements. Auditing: A Journal of Practice \& Theory, 23(1), 69-87. 
Abdul Hamid, M. A. \& Mohamed, S. A. N., A. M. (1999). Effectiveness of audit committee: some evidence. Akauntan Nasional, 12(1), 5-10.

BRC. (1999). Blue Ribbon Committee on Improving the Effectiveness of Corporate Audit Committees (BRC). (1999) Report and Recommendations of Blue Ribbon Committee on Improving the Effectiveness of Corporate Audit Committees, New York and Washington, DC: NYSE and NASD.

Carcello, J. V. \& Neal, T. L. (2000). Audit committee composition and auditor reporting. The Accounting Review, 75(4), 453-467.

Dalton, D. R., Daily, C. M., Johnson, J. L. \& Ellstrand, A. E. (1999). Number of directors and financial performance: A meta-analysis. Academy of Management Journal, 42(6), 674-686.

DeZoort, F. T. \& Salterio, S. E. (2001). The effects of corporate governance experience and financial-reporting and audit knowledge on audit committee members' judgments. Auditing: A Journal of Practice \& Theory, 20(2), 31-47.

Dorff, M. B. (2006). The Group Dynamics Theory of Executive Compensation. Bepress Legal Series, 1694.

Eichenseher, J. W. \& Shields, D. (1985). Corporate director liability and monitoring preferences. Journal of Accounting and Public Policy, 4(1), 13-31.

Eisenberg, T., Sundgren, S. \& Wells, M. T. (1998). Larger board size and decreasing firm value in small firms. Journal of financial economics, 48(1), 35-54.

Fama, E. F. \& Jensen, M. C. (1983). Separation of ownership and control. Journal of law and economics, 26(2), 301-325.

FCCG. (1999). Finance committee on corporate governance. Report on corporate governance,malaysia.

Hussain, S. H. \& Mallin, C. (2003). The dynamics of corporate governance in Bahrain: structure, responsibilities and operation of corporate boards. Corporate governance: an international review, 11(3), 249-261.

Jensen, M. C. (1986). Agency costs of free cash flow, corporate finance, and takeovers. The American Economic Review, 76(2), 323-329.

Menon, K. \& Deahl Williams, J. (1994). The use of audit committees for monitoring. Journal of Accounting and Public Policy, 13(2), 121-139.

Opler, T., Pinkowitz, L., Stulz, R. \& Williamson, R. (1999). The determinants and implications of corporate cash holdings. Journal of financial economics, 52(1), 3-46.

Pearce, J. A. \& Zahra, S. A. (1992). Board composition from a strategic contingency perspective. Journal of management studies, 29(4), 411-438.

Pierce, J. \& Zahra, S. (1992). Board composition from a strategic contingency perspective. Management Studies, 29, 411-438.

Pincus, K., Rusbarsky, M. \& Wong, J. (1990). Voluntary formation of corporate audit committees among NASDAQ firms. Journal of Accounting and Public Policy, 8(4), 239-265.

Raghunandan, K. \& Rama, D. V. (2007). Determinants of audit committee diligence. Accounting Horizons, 21(3), 265-279.

Raghunandan, K., Rama, D. V. \& Read, W. J. (2001). Audit committee composition,"gray directors," and interaction with internal auditing. Accounting Horizons, 15(2), 105-118.

Rahman, R. A. \& Ali, F. H. M. (2006). Board, audit committee, culture and earnings management: Malaysian evidence. Managerial Auditing Journal, 21(7), 783-804.

Vinten, G. A. L. C. (1993). Audit committee and corporate control. Managerial Auditing Journal of Accountancy, 8(3), 113-142

Yermack, D. (1996). Higher market valuation of companies with a small board of directors. Journal of financial economics, 40(2), 185-211.

Zhang, Y., Zhou, J. \& Zhou, N. (2007). Audit committee quality, auditor independence, and internal control weaknesses. Journal of Accounting and Public Policy, 26(3), 300-327. 